\title{
LITERASI DIGITAL : PELATIHAN BAGI PEMUDA GEREJA GMIM BUKIT ZAITUN SEA MITRA
}

\author{
Alfrina Mewengkang \\ Jurusan PTIK, Fakultas Teknik, \\ Universitas Negeri Manado \\ mewengkangalfrina@unima.ac.id \\ Marssel Michael Sengkey \\ Universitas Negeri Manado \\ mmsengkey@unima.ac.id \\ Salaki Reynaldo Joshua \\ Universitas Sam Ratulangi \\ salakirjoshua@unsrat.ac.id
}

\begin{abstract}
Abstrak
Kegiatan pengabdian ini dilaksanakan bagi Pemuda Gereja GMIM Bukit Zaitun Sea Mitra dengan melakukan pengabdian pada peningkatan pemahaman yakni dimulai dari aspek Pengertian Literasi Digital, Pentingnya Literasi Digital, Dampak Literasi Digital, dan Elemen Literasi Digital. Kegiatan ini akan mengambil sebelas responden yang merupakan perwakilan dari sebelas kelompok pelayanan sebagai sampel untuk melihat tingkat pemahaman dari lima aspek yang ditekankan dengan tahapan Pre-Test, pelatihan dan Post-Test. Hasil pengabdian ini akan diukur melalui hasil akhir Post-Test guna mengevaluasi pengaruh setelah diberikan pelatihan literasi digital kepada peserta yakni pemuda gereja.
\end{abstract}

Kata Kunci : Literasi Digital, Pemahaman, Pemuda Gereja 


\section{PENDAHULUAN}

Perkembangan teknologi yang begitu pesat terjadi dalam satu dekade terakhir, dimana teknologi layar sentuh muncul sebagai barang mewah, hingga pada saat ini gawai menjadi benda yang bisa dimiliki oleh siapa saja, dari kelas ekonomi sosial manapun (Stella Stefany1, Nurbani2, dan Badarrudin, 2017). Melalui Kemajuan teknologi informasi saat ini berdampak pada sumber daya informasi digital sangat melimpah. Kemudahan akses dan melimpahnya informasi yang dapat diperoleh melalui internet, disisi lain justru mengakibatkan mahasiswa menjadi kurang selektif dalam memilih sumber informasi yang akan digunakannya (Nurjanah E, Rusmana A, dan Yanto A., 2017), hal ini juga dirasakan dalam dunia akademik, hal ini termuat pada penelitian Akbar M.F dan Anggaraeni F. D, 2017 serta Hague dan Payton, 2010 dimana era digital berdampak pada bidang pendidikan khususnya di Perguruan Tinggi.

\section{Literasi Digital}

Kurnianingsih I, Rosini dan Imayati $N$ (2017) dalam Jurnal Pengabdian masyarakat menuliskan bahwa Istilah literasi digital pertama kali dikemukakan oleh Paul Gilster (1997) sebagai kemampuan memahami dan menggunakan informasi dari berbagai sumber digital. Ia me- ngemukakan bahwa literasi digital merupakan kemampuan menggunakan teknologi dan informasi dari piranti digital secara efektif dan e sien dalam berbagai konteks, seperti akademik, karier, dan kehidupan sehari-hari. Bawden (2001) memperluas pemahaman baru mengenai literasi digital yang berakar pada literasi komputer dan literasi informasi. Literasi komputer berkembang pada dekade 1980an ketika komputer mikro semakin luas dipergunakan, tidak hanya di lingkungan bisnis, tetapi juga masyarakat. Sementara itu, literasi informasi menyebar luas pada dekade 1990-an manakala informasi semakin mudah disusun, diakses, dan disebarluaskan melalui teknologi informasi berjejaring. Martin

(2006:155) merumuskan de nisi literasi digital sebagai berikut.

Gilster pada tahun 1997 sebagaimana dikutip dalam Belshaw (2011) menyatakan bahwa "Digital literacy is the ability to understand and use information in multiple formats from a wide variety of sources when it is presented via computers". Menurut Gilster literasi digital merupakan kemampuan untuk memahami dan menggunakan informasi dalam berbagai format yang berasal dari berbagai sumber digital yang ditampilkan melalui komputer (Belshaw D.A.J., 2011). Martin \& Allan (2008) merumuskan beberapa dimensi literasi digital berikut ini:

1. Literasi digital melibatkan kemampuan aksi digital yang terikat dengan kerja, pembelajaran, kesenangan dan aspek lain dalam hidup sehari-hari. 
2. Literasi digital secara individual bervariasi tergantung situasi sehari-hari yang ia alami dan juga proses sepanjang hayat sebagaimana situasi hidup individu itu.

3. Literasi digital dibentuk oleh namun lebih luas dari literasi teknologi komunikasi informasi.

4. Literasi digital melibatkan kemampuan mengumpulkan dan menggunakan pengetahuan, teknik, sikap dan kualitas personal selain itu juga kemampuan merencanakan, menjalankan dan mengevaluasi tindakan digital sebagai bagian dari penyelesaian masalah/tugas dalam hidup.

5. Literasi digital juga melibatkan kesadaran seseorang terhadap tingkat literasi digitalnya dan pengembangan literasi digital.

\section{Media Digital}

Media baru yang sekarang banyak digunakan oleh hampir semua lapisan masyarakat adalah sosial media. Media ini yang dikenal dengan istilah jejaring sosial, media ini diantaranya adalah facebook, twitter dan youtube. Di Indonesia pengguna facebook menempati peringkat ketiga dunia setelah Amerika Serikat. Sedangkan pengguna twitter di Indonesia peringkatnya tidak beda jauh dengan facebook. Sedangkan youtube adalah situs web video sharing (berbagi video) yang popular digunakan. Umumnya youtube berisi video klip, film, TV serta video yang sengaja dibuat serta diunggah dengan berbagai tujuan tertentu (Silvana H \& Cecep, 2018). Aktivitas media digital antara lain: bergabung dalam SNSs (situs jejaring sosial), mengunakan blog ataupun mikroblog, melakukan chatting melalui pesan instan (instant messaging), bermain game online, bergabung dalam dunia maya (virtual world), menggunakan papan buletin (bulletin boards), hingga mengunduh musik dan video secara online (Subrahmanyam, Smahel \& David, 2010).

\section{METODE}

Kegiatan yang dilaksanakan berupa pelatihan literasi informasi tingkat dasar. Materi pelatihan disesuaikan dengan kebutuhan para pemuda agar dapat menjawab berbagai permasalahan literasi yang ada di lingkungan Gereja.

Pada tahap persiapan, tim pengabdian ini melaksanakan beberapa kegiatan, di antaranya koordinasi dengan para peserta melalui penyebaran undangan pelatihan literasi informasi bagi mitra yang menjadi sasaran pengabdian. Langkah berikutnya ialah persiapan pembuatan materi pelatihan literasi digital dengan rincian materi sebagai berikut. 


\begin{tabular}{ll}
\hline No & \multicolumn{1}{c}{ Topik } \\
\hline 1 & Pre-Test \\
\hline 2 & Pengertian Literasi Digital \\
3 & Pentingnya Literasi Digital \\
4 & Dampak Literasi Digital \\
5 & Elemen Literasi Digital \\
\hline 6 & Post-Test \\
\hline
\end{tabular}

Tabel 1. Topik Materi Pelatihan

Modul yang digunakan dalam sesi pelatihan ini berupa materi presentasi yang mencakup materi dalam Tabel 1.

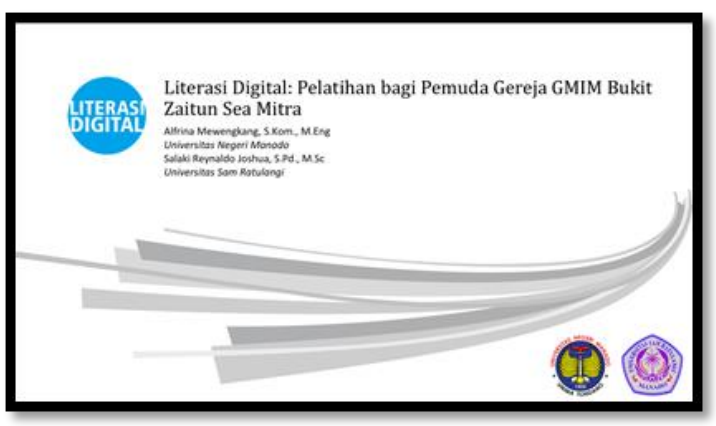

Gambar 1. Materi Pengabdian Literasi Digital

\begin{tabular}{ll}
\hline No & \multicolumn{1}{c}{ Pertanyaan } \\
\hline 1 & \\
Pre-Test & Nama \\
Post-Test & \\
2 & \\
Pre-Test & Jenis Kelamin \\
Post-Test & \\
3 & \\
Pre-Test & Pendidikan Terakhir \\
Post-Test & \\
4 & \\
Pre-Test & Apakah Saudara/ri sudah memahami apa \\
Post-Test & yang dimaksud dengan Digital Literacy/ \\
5 & Literasi Digital? \\
Pre-Test & Apakah Saudara/ri mengetahui pentingnya \\
Post-Test & Digital Literacy/Literasi Digital? \\
6 & \\
Pre-Test & Apakah Saudara/ri mengetahui dampak \\
Post-Test & Digital Literacy/Literasi Digital? \\
7 & \\
Pre-Test & Apakah Saudara/ri mengetahui manfaat \\
Post-Test & Digital Literacy/Literasi Digital? \\
8 & \\
Pre-Test & Apakah Saudara/ri mengetahui element \\
Post-Test & Digital Literacy/Literasi Digital?
\end{tabular}

Post-Test

\begin{tabular}{llc}
\hline No & \multicolumn{1}{c}{ Indikator } & Target Capaian \\
\hline 1 & $\begin{array}{l}\text { Mengetahui Pengertian } \\
\text { Literasi Digital }\end{array}$ & $80 \%$ \\
2 & $\begin{array}{l}\text { Mengidentifikasi } \\
\text { Literasi Digital }\end{array}$ & $80 \%$ \\
3 & $\begin{array}{l}\text { Menguraikan Dampak Literasi } \\
\text { Digital }\end{array}$ & $80 \%$ \\
4 & $\begin{array}{l}\text { Mengidentifikasi } \\
\text { Literasi Digital Elemen }\end{array}$ & $80 \%$ \\
\hline & Tabel 2. Indikator Pencapaian dan Tolak
\end{tabular}

\section{Ukurnya}

Untuk mengukur tingkat keberhasilan kegiatan pengabdian ini, peserta diberikan kuesioner pre-test (sebelum) pelatihan dan kuesioner post-test (sesudah) pelatihan dalam bentuk kuesioner online yang berisi tes pengujian kemampuan literasi informasi. Tahap ini dimaksudkan untuk mengetahui kemampuan literasi informasi para peserta pelatihan. Berikut merupakan da ar pertanyaan yang diajukan pada kegiatan pelatihan.
Berdasarkan jawaban kuesioner terlihat perubahan kemampuan peserta sebelum dan sesudah mengikuti pelatihan. Selain itu, sebagai proses pendampingan.

\section{HASIL DAN PEMBAHASAN}

\section{Pelatihan Literasi Digital}

Hasil dan pembahasan disampaikan secara jelas. Gambar dan tabel yang disertakan dalam makalah dapat diletakkan diantara teks makalah atau sebagai lampiran di akhir makalah. Setiap gambar/grafik/bagan harus format jpg atau sejenisnya. Gambar/grafik/bagan yang tidak berformat jpg menyebabkan layout berantakan. Apabila gambar/grafik/bagan tidak berformat jpg maka panitia akan mengembalikan untuk direvisi sesuai 
ketentuan tersebut. Masing masing gambar/grafik/bagan dan tabel harus diberi nomor urut.

Pelatihan Literasi Digital dilaksanakan di Gedung Gereja GMIM Bukit Zaitun Sea pada 05 Juli 2019 yang berlangsung pukul 18:00 -21.00. Pelatihan dilaksanakan selama tiga jam, sesuai dengan waktu yang ditargetkan. Narasumber kegiatan terdiri atas dua orang dosen.

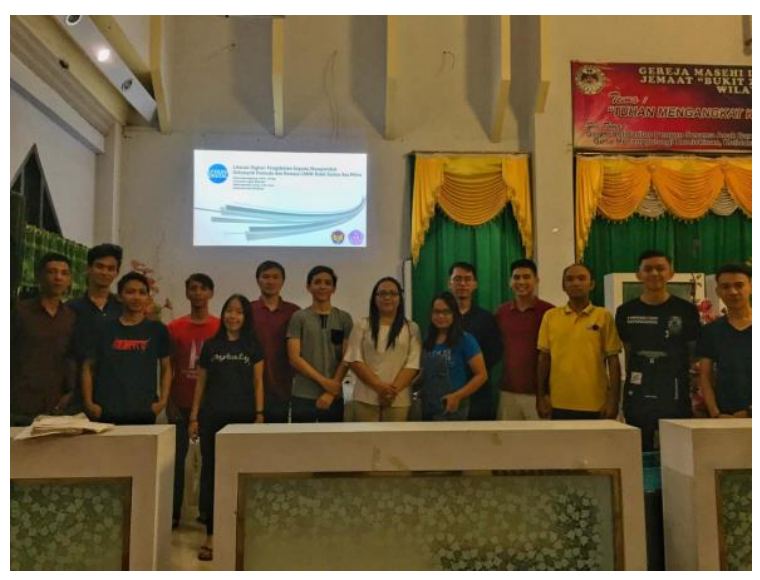

Gambar 1. Tim dan Peserta Pengabdian

Jumlah peserta keseluruhan ialah sebelas orang pemuda-pemudi yang berasal yang merupakan perwakilan dari 11 kelompok pelayanan di GMIM Bukit Zaitun Sea Mitra. Pada gambar 2 dan 3 ditampilkan data responden berdasarkan jenis kelamin dan pendidikan terakhir.
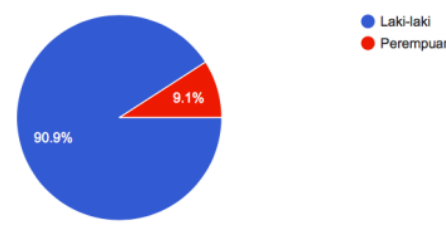

Gambar 2. Jenis Kelamin Responden

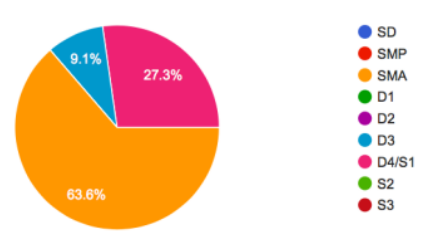

Gambar 3. Pendidikan Terakhir Responden

\section{Pemahaman Terhadap Literasi Digital}

Kegiatan pengabdian yang dilaksanakan melalui presentasi materi yang mencakup empat komponen penting materi. Pada bagian ini peserta memperoleh gambaran tentang Pengertian Literasi Digital, Pentingnya Literasi Digital, Dampak Literasi Digital, dan Elemen Literasi Digital. Hasil pengisian kuesioner oleh para peserta disajikan sebagai berikut.

\subsection{Pengertian Literasi Digital}

Pada bagian ini responden diberikan pertanyaan Apakah Saudara/ri sudah memahami apa yang dimaksud dengan Digital Literacy/ Literasi Digital?. Hasil PreTest dan Post-Test pada gambar 4 dan 5 menunjukan terjadi peningkatan tingkat pemahaman dari (36.4\%) menjadi (90.9\%).

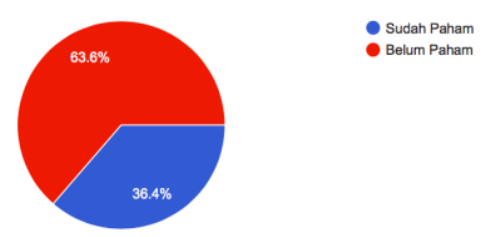

Gambar 4. Pre-Test Pemahanan Literasi Digital 


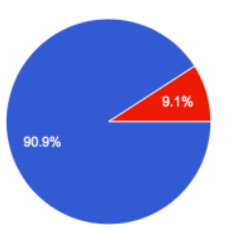

Gambar 5. Post-Test Pemahanan Literasi Digital

\subsection{Pentingnya Literasi Digital}

Pada bagian ini responden diberikan pertanyaan Apakah Saudara/ri mengetahui pentingnya Digital Literacy/ Literasi Digital?. Hasil Pre-Test dan Post-Test pada gambar 6 dan 7 menunjukan terjadi peningkatan pentingnya Literasi dari (36.4\%) menjadi (90.9\%).

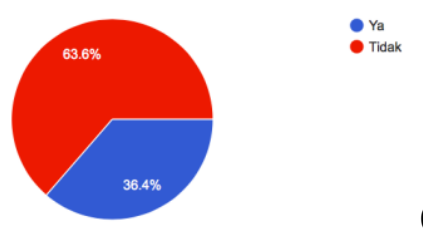

ambar 6. Pre-Test Pentingya Literasi Digital

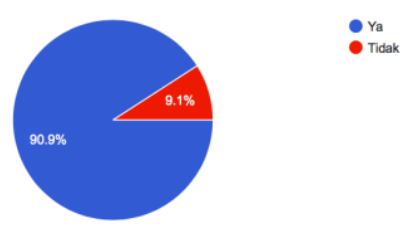

Gambar 7. Post-Test Pentingya Literasi Digital

\subsection{Dampak Literasi Digital}

Pada bagian ini responden diberikan pertanyaan dua pertanyaaan, pertama Apakah Saudara/ri mengetahui dampak Digital Literacy/ Literasi Digital? dan kedua Apakah Saudara/ri mengetahui manfaat Digital Literacy/ Literasi Digital?. Hasil PreTest dan Post-Test pada gambar 7 dan 8 menunjukan terjadi peningkatan dampak Literasi dari (36.4\%) menjadi (90.9\%) dan pada gambar 9 dan 10 menunjukan terjadi peningkatan manfaat Literasi dari (36.4\%) menjadi (90.9\%).

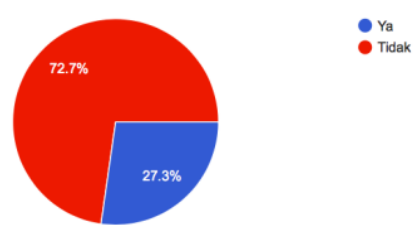

Gambar 7. Pre-Test Dampak Literasi Digital

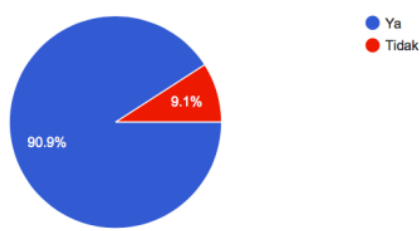

Gambar 8. Post-Test Dampak Literasi Digital

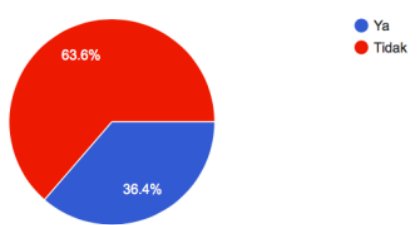

Gambar 9. Pre-Test Manfaat Literasi Digital

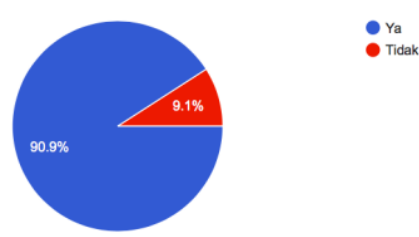

Gambar 10. Post-Test Manfaat Literasi Digital

\subsection{Elemen Literasi Digital}

Pada bagian ini responden diberikan pertanyaan dua pertanyaaan Apakah Saudara/ri mengetahui element Digital 
Literacy/ Literasi Digital?. Hasil Pre-Test dan Post-Test pada gambar 11 dan 12 menunjukan terjadi peningkatan pemahaman mengidentifikasi elemen Literasi dari (9.1\%) menjadi (81.\%).
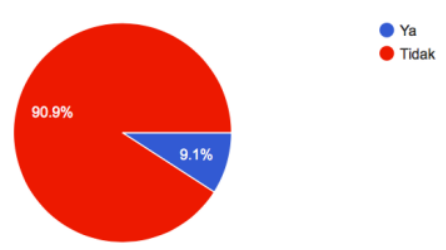

Gambar 11. Pre-Test Elemen Literasi Digital

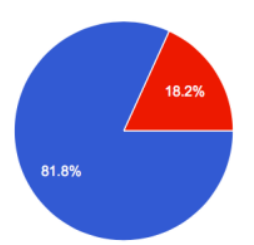

- Ya

Gambar 12. Post-Test Elemen Literasi Digital

\section{KESIMPULAN DAN SARAN}

Pelaksanaan kegiatan pengabdian berupa pelatihan literasi digital kepada pemuda Gereja GMIM Bukit Zaitun Sea Mitra yang diselenggarakan oleh Program Studi Teknologi Informasi dan Komunikasi Universitas Negeri Manado dan Program Studi Teknik Informatika Universitas Sam Ratulangi mampu memberikan kontribusi positif terhadap peningkatan kemampuan literasi digital kepada peserta dalam aspek Pengertian Literasi Digital, Pentingnya Literasi Digital, Dampak Literasi Digital, dan Elemen Literasi Digital. Kedepannya diharapkan perlu pengembangan peningkatan pemahaman Literasi Digital dengan ruang lingkup yang lebih luas dengan mengundang peserta yang berasal dari daerah yang berbeda, sehingga diharapkan pemuda-pemudi kedepannya akan lebih cerdas dalam aspek Pengertian Literasi Digital, Pentingnya Literasi Digital, Dampak Literasi Digital, dan Elemen Literasi Digital.

\section{KEPUSTAKAAN}

Akbar M.F dan Anggaraeni F. D. (2017). Teknologi dalam Pendidikan: Literasi Digital dan Self-Directed Pada Mahasiswa Skripsi. Jurnal INDEGENOUS, Vol.2, No.1.

Belshaw D.A.J. (2011). What id "Digital Literacy"?. Durham University, United Kingdom.

Gilster. (1997). Digital Literacy. New York: Wiley.

Hague dan Payton. (2010). Digital Literacy Across the Curriculum. Bristol : Futurelab.

Kurnianingsih I, Rosini \& Imayati N. (2017). Upaya Peningkatan Kemampuan Literasi Digital bagi Tenaga Perpustakaan Sekolah dan Guru di Wilayah Jakarta Pusat melalui Pelatihan Literasi Informasi. Jurnal Pengabdian Kepada Masyarakat, Vol 3, No.1. Martin \& Allan. (2008). Digital Literacy and the 'Digital Society' daLAM Lankshear C. dan Knobel, M. Digital Literacies: concepts, policies and practies. Die Deutsche Bibliotek.

Nurjanah E, Rusmana A, dan Yanto A. (2017). Hubungan Literasi Digital dengan 
Kualitas Penggunaan E-Resources. Jurnal Lentera Pustaka UNDIP 3 (2).

Silvana H \& Cecep. (2018).

Pendidikan Literasi di Kalangan Usia Muda

di Kota Bandung. Jurnal Ilmu Pendidikan PEDAGOGIA Vol. 16, No.2.

Stella Stefany1, Nurbani2, \& Badarrudin. (2017). Literasi Digital dan Pembukaan Diri: Studi Korelasi Penggunaan Media Sosial Pada Pelajar Remaja di Kota
Medan. Jurnal Pemikiran dan Penelitian Sosiologi SOSIOGLOBAL 2 (1).

Subrahmanyam, Smahel \& David (2010). Digital Youth: The Role of Media in Development. London: Springer Science \& Business Media. 